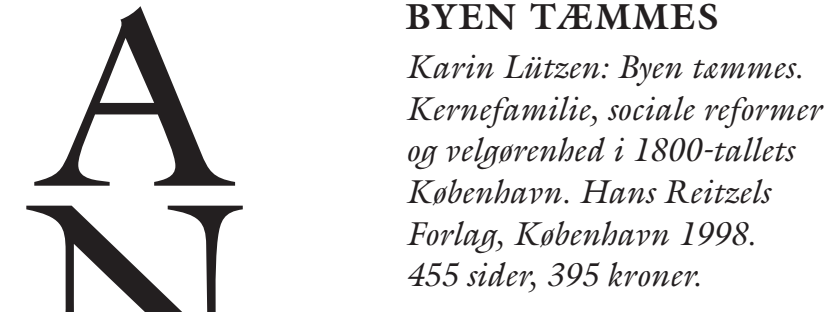

I følge Karin Lützen er den danske velfærdsstat ikke en socialdemokratisk opfindelse, der kan føres tilbage til den socialdemokratiske socialminister Steincke og socialreformen i 1933. Velfærdsstatens og dens grundlæggende principper har en meget længere historie, hvis rødder rækker tilbage til middelalderen. I dens nuværende udformning er den danske velfærdsstat en konsekvens af 1800-tallets private velgørenhed, som Lützen ser som en forløber for Velfærdsstaten i højere grad end Det offentlige Fattigvæsen. Karin Lützens bog om det 19. århundredets København er historien om udviklingen af de forestillinger og normer, som dem vi kender, som velfærdsstaten bygger på. Bogen er rig på interessante perspektiver, har en utrolig spændvidde og rigdom af detaljer.

Lützen skriver kønshistorie, ikke kvindehistorie. Hendes skildringer af filantropien som velfærdsstatens rødder er historien om kvinders emancipation uden, at omsorgsfuldhed fremhæves som særlig egenskab eller ensidigt idealiseres som udgangspunkt for velfærdsstaten. Filantropien som een form for samfundsmæssig virke, begge køn er engageret i, sættes i relation til både jura og politik. Filantropien udvider den private sfære, uden at kvinder der- for forlader familiesfæren og kommer 'ud i offentligheden'. Eksempelvis organiseres hjem for 'faldne piger' som en kvindedomineret familie og med kvinder som medlemmer.

Bogens røde tråd spindes omkring forandringerne i mellemklassen, kernefamilien og idealerne om 'det gode liv' i fire afsnit om: Byen, Fattigdommen, Prostitutionen og Det Kristne Værn. Afsnittet om Byen fortæller, om tilblivelsen af det moderne som mødet mellem forskellige klasser, køn og folk, der ikke kender hinanden. Lützen skildrer levende byens ubeherskede mylder af liv. Et udgangspunkt for velfærdsstatens tilblivelse var ifølge Lützen, at klassernes og kønnenes møde i det offentlige rum skulle tæmmes. Kønnet i 1800-tallet var foranderligt, egenskaber var endnu ikke bundet til et køn. Ligesom der fandtes kvindedominerede familiestrukturer, kunne kvinder også være "Fader".

Karin Lützens bog er meget levende og farverig, nogle steder næsten malerisk skildring af bylivet og dens udfordringer i 1800 tallets København. Bogen kan nærmest læses som en roman. Den er meget empirisk, let læseligt og henvender sig da også til en bredere gruppe end blot fagfolk. Men det som er bogens styrke, er samtidig dens svaghed. Tag for eksempel afsnittet om Byen. Det er meget deskriptivt, og kilderne får ligesom lov til at tale for sig selv, men det er tvivlsomt, om de nu også kan det. Tidens beskrivelse af nervesygdomme får således lov til at fremstå som en pris, mænd faktisk 
skulle til at betale for byens moderne liv. En stor del af kilderne er tekster publiceret $\mathrm{i}$ forskellige medier, der i positivismens ånd bliver læst som sandfærdige levninger, uden at der gøres rede for kildeudvalgets begrænsninger og muligheder. Der tages ikke højde for, at det er borgerskabets dannede mænd, der er kildernes ophavsmænd, og at det er deres øjne, der bestemmer synet på klassernes og kønnenes møde i byen. Kilder, hvor kvinder eller mindre priviligerede folk giver deres version af borgerskabet eller den nye mellemklasse, er fraværende, uden at dette faktum problematiseres. Ligeledes ser 1800tallets København ud til at være en by uden en overklasse, hvilket næppe er troværdigt. Hvad betød velfærdsstaten for den? Skildringerne af samlivsproblemer i familierne beskrives kun for den moderne kernefamiliens vedkommende.

Dermed opstår det indtryk, at der før kernefamiliens opståen og udbredelse eller uden for kernefamilien ikke fandtes eller findes samlivsproblemer. Kernefamiliens opståen får lov til at fremstå som samlivsproblemernes centrale årsag, men er det troværdigt, at livet før eller uden for kernefamilien absolut er eller var lykkeligere?

Karin Lützen har imidlertid en række gode analytiske pointer. Fremkaldelsen af kernefamilien og den hjemmegående husmor, som ideal, fremstår som årsag til fordømmelsen af andre samlivsformer, herunder homoseksuelle. Forestillinger om kernefamilien bliver indlemmet $\mathrm{i}$ idealet om 'det gode liv', og sociale reformer og velgørenhed gjorde det muligt at virkeliggøre forestillingerne med udgangspunkt i byen og dens liv. Marx og Engels optræder her i en uvant rolle som middelstandsmænd, der i deres socialistiske idealsamfund opretholder middelstandens familieideal. Det er konstituerende for kernefamilien som ideel livsform, at samtidig med, at kernefamilien blev konstrueret som en udbredt samlivsform, blev den også sentimentaliseret og dens opløsning begrædt.

Det er interessant at opleve, at nogle kildebeskrivelser fra slutningen af det 19. århundrede, hvor konen og børnene glædeligt hilser den fra dagens arbejde hjemkommende mand, i overraskende grad minder om en reklamefilm fra 1950erne.

Filantropiens oprindelse og udvikling analyseres i sammenhæng med byens sociale, økonomiske og politiske forandringer. Velfærdsstatens udvikling 1830 - 1895 bygger på en helt bestemt forestilling om det gode liv. Middelstandens velgørenhed bygger ifølge Lützen ikke på en idé om uretfærdighed, men på en idé om, at de fattige gerne vil leve som middelstanden, og de skal hjælpes på vej. Fattigforsørgelsen blev en grundlovsikret ret $\mathrm{i}$ 1849. Valgretten var dengang knyttet til økonomisk selvstændighed, dvs. fattighjælpsmodtagere kunne ikke vælge. Et historisk overblik over fattigforsørgelsen fra 1700 tallet viser bl.a., at denne opdeling mellem de hjælpeløse fattige og de arbejdsførende kan føres tilbage til Kong Christian II og i princippet gælder til i dag. Be- grebet 'værdig trængende' blev til i 1856, fordi man tager højde for fattigdom som følge af økonomiske svingninger og dermed den frie konkurrences sociale følger. Selvom første private velgørenhedsinitiativer kan føres tilbage til 1788, hvor man indrettede forsikringsordninger for middelstanden $\mathrm{i}$ tilfælde af armod, bliver det offentlige fattigvæsen først i 1869 udvidet med private initiativer. Fattigvæsenet skulle også sørge for de fattiges livsførelse, og middelstandens dyder om orden, renlighed, ædruelighed, sædelighed og især seksuel selvbeherskelse blev opstillet som ideal af det offentlige fattigvæsen og brugt som målestok af den private velgørenhed. God opførsel var en betingelse, ellers anså man ikke de fattige som ofre, men betragtede deres fattigdom som selvforskyldt og de fattige derfor ikke som værdige til hjælp. Oplysning eller opdragelse blev allerede fra 1845 anset som reel forebyggelse mod armod; den skulle ikke ændre ved samfundets struktur, men styrke de fattige moralsk for at gøre dem mere tilfredse med deres plads i samfundet. Velfærdsstaten holdt moralprædiker under dække af en oplysningspligt.

Mellemklassens kvinder viste solidaritet ved at udvide hjemmet. De to sig ikke af forbrydere og drankere, men af kvinder og børn. De bekæmpede den offentlige prostitution og mente at give deres magt videre når de krævede, at også arbejderklassens kvinder skulle lære, at deres plads var i hjemmet. Mens man betragtede 'de 
hvide slaver', offentlige kvindelige prostituerede, som ofre og derfor værdige til hjælp, var det i tilfælde af mandlig homoseksualitet omvendt: de sædelighedsbevidste københavnere betragtede homoseksualitet som et medfødt arveanlæg og krævede hårde straffe. Interessant er det, at homoseksualitet allerede før heteroseksualiteten blev defineret som et klinisk fænomen. Heteroseksualitetens efterfølgende definition var nødvendig for at kunne danne grundlag for en definition af homoseksualitet som en afvigelse fra noget. Lützen argumenterer for, at det imidlertid er afgørende, at det er kernefamilien, ikke heteroseksualitet, som homoseksualitet defineres som afvigende fra. Lützens xrinde er således også at søge at bidrage til en dekonstruktion af heteroseksualitet via en historisk analyse af kernefamiliens opståen som den mest efterstræbelsesværdige livsform.

Lützen knytter an til dagens aktuelle velfærdspolitiske diskussioner og ser dem i perspektivet af deres historiske udvikling. Kernefamilien blev først virkelighed for alle klasser i 1950erne. Lützen hævder, at homoseksuelles nyere ret til xgteskab er en konsekvens af både ægteskabets faldende betydning siden 1970erne og kernefamiliens opløsning. Selvom det umiddelbart virker indlysende, så må man undre sig over en inkonsistens i tolkningernes teoretisk-metodiske grundlag. Mens kernefamiliens opløsning tidligere blev tolket som en konstituerende del for dens opbygning og opretholdelse ikke som leveform, men som et ideal, fremstår den nu som et reelt faktum i stedet for en nødvendig fortælling, der skal legitimere den aktuelle velfærdsstatspolitik og dens grundlag. For Lützen hævder også, at kernefamilien på trods af dens faldende betydning for det levede liv stadigvæk er den grundlæggende forestilling for velfærdsstatens politik. Hun nævner her som eksempler diskussionerne om retten til kunstig befrugtning og adoption. Hun påpeger interessante paralleller mellem det 19. århundredets kristne filantropi og det 20. århundredetes moderne socialrådgivere, der stadigvæk anvender mange af de samme vurderingskriterier. Det er også tankevækkende, at fattighjælpsmodtagere fortsat skal yde før de kan nyde. Den dag i dag opretholdes kravet i 1500tallets bettlerlovgivning om at bistandsklienter skal arbejde, hvis de kan, og stå til rådighed for arbejdsmarkedet. Lützens pointe er overbevisende:

Velfærdsstaten er ikke værdifri, men formidler et klassebestemt billede af 'det gode liv'.

Bogen er absolut anbefalelsesværdig for kønshistorikere, velfærdsstatsforskere og alle, der elsker at fordybe sig i en rigtig god og levende bog.

\section{Iris Rittenhofer,}

Forsknings-adjunkt.

Ph.d. og forkvinde for Foreningen for Kvinde- og Konsforskning $i$ Danmark.

\section{FÆDRE OG FØDSLER}

Svend Aage Madsen, Hanne

Munck og Marianne Tolstrup:

Fadre og fødsler. Frydenlund, 1999. 172 sider. Pris: $228 \mathrm{kr}$.

$\mathrm{B}$ ogen udspringer af et delprojekt under forskningsprogrammet "Fædres relationer til deres spæd- og småbørn". Formålet er at "tilvejebringe en psykologisk forståelse af det særlige ved fædres relationer til deres spæd- og småbørn og at udvikle en psykologisk forståelse heraf." Denne forståelse tænkes brugt i konkrete sammenhænge, hvor fædres relationer til deres spædog småbørn er central, bl.a. ved fødsler og fødselsforberedelse. Fremgangsmåden i projektet er en spørgeskemaundersøgelse af 163 tilfældigt udvalgte mænd og interview med 23 ligeledes tilfældigt udvalgte mænd før og efter deres barns fødsel. Dertil interview med ti jordemødre. Samtlige data vedrører fødsler på Rigshospitalet i København.

Først præsenteres læseren for sensationen, at fædre nu deltager i deres børns fødsler. Det bliver dog hurtigt klart, at det blot drejer sig om, at fædre er til stede $\mathrm{i}$ fødestuen på hospitalet mens fødslen står på. Senere uddybes, at en mindre del af fædrene klipper navlestrengen over (et fænomen, der ifølge en af de interviewede jordemødre er "lidt trendy for tiden") eller f.eks. tager imod barnet. Mere substantielt peges dog i interviewundersøgelsen af jordemødre på, at fædrene kan spille en væsentlig rolle i kommunikationen mellem sundhedspersonalet og den fødende kvinde. 
Inden disse spændende resultater bliver fremlagt, når bogen vidt omkring i forskellige perspektiver på fødsler, børn og forældre: kulturanalyse, socialiseringsteori, udviklingspsykologi og især tilknytningsteori bliver præsenteret, omend det ville være synd at kalde bogen tværdisciplinær eller -teoretisk. Kulturanalysen trækkes ind for at etablere pointen om det historisk nye i frdrenes tilstedeværelse under selve fødslen, hvorefter "fortiden" og de "eksotiske kulturer" forlades for i stedet at forsøge at etablere en vidensbaseret tilgang $\mathrm{i}$ undersøgelsen af fædres deltagelse. Det kan iøvrigt virke lidt pudsigt, at forfatterne selv præsenterer et eksempel, der falsificerer pointen om det historisk nye i fædres tilstedeværelse.

Vi făr et kort indblik i forskningen i "couvade" og "engrossment" fænomenerne, henholdsvis ritualer hvor faderen lever med i fødslen for symbolsk at hjælpe den fødende med at bære smerterne og adfærds- og følelsesreaktioner kendetegnet ved faderens engagement, opslugthed og betagethed af den nyfødte.

Efter denne rundvisning i raritetskabinettet begynder bogens egentlige tråd med kapitel fire på side 25 . Her præsenteres udviklingen af kønsroller og organiseringen af fødsler i Danmark. Samtidig med den stigende erhvervsfrekvens blandt kvinder bliver fødslerne flyttet ind på hospitalerne i et omfang så kun $0,9 \%$ af alle fødsler i 1975 foregik i hjemmet. Tesen er, at hospitalerne behandler de gravide kvinder som alle andre patienter, dvs. isolerer og passiviserer dem, for derefter, når barnet bliver født, at behandle det på samme måde, med den konsekvens at en nybagt mor på Frederiksberg Hospital i 1974 kun har barnet hos sig 3-4 timer i døgnet. Når denne praksis støder sammen med de samtidige tendenser til kritisk indstilling til autoriteter og begyndende organisering i brugergrupper, blandt andre Foreldre og Fødsel, opstår et krav om forandring, der i første omgang fører til, at mor og barn ikke adskilles og som en logisk progression også far făr adgang til andet end at betragte sit barn gennem en glasrude. Fra barselsstuen til fødestuen er afstanden ikke så stor: i 1999 opholder ca. $90 \%$ af fædrene sig her mens fødslen pågår.

Parallelt med disse forandringer i hospitalernes praksis, udvikles de udviklingspsykologiske teorier om det kompetente barn og tilknytningsadfærd. Heraf uddrages i bogen den lære, at børnene har brug for kontakt til forældrene umiddelbart efter fødslen, samt at fædrene hverken er mere eller mindre vigtige end mødrene - når bortses fra amningen. Vi hører også om socialiseringens kønsspecifikke karakter, omend dette på samme måde som kapitlet om kulturanalyse, forekommer noget malplaceret - især da forfatterne ikke anvender dets pointer til andet end at konstatere, at fædrene psykologisk er "i stand til” at knytte sig til deres børn. Hvis de ellers kan få fri fra deres arbejde, fristes jeg til at tilføje.
De to empiriske kapitler belyser fædrenes tilstedeværelse fra deres egen vinkel og fra jordemødrenes. Det er desværre svært at bedømme kvaliteten her, da der ikke redegøres for undersøgelsens metode - end ikke svarprocenter opgives. Det betyder blandt andet, at det er svært at bedømme udtalelser og spørgeskemabesvarelser ud over face value. Når en far på spørgsmålet om, hvorfor han er med ved fødslen (det stillede spørgsmål refereres heller ikke) svarer: "Det virker forkert ikke at ville overvære sine egne børns fødsel”, er det så blot en gentagelse af et kulturelt, moralsk påbud, eller udtryk for en umiddelbar følelsesmæssig oplevelse? Undertegnede læser er - ikke mindst i lyset af dobbelt negationen i udsagnet - i tvivl. Det fremstår imidlertid som eksemplarisk for bogens analyse, at denne type spørgsmål ikke stilles.

I det mindste hævdes dog en vis pluralisme i de tolkninger, der foretages: mange frdres optagethed af apparaturet, f.eks. en vemåler, udlægges som udtryk for kærlighed, bekymring, ansvarsfølelse og tilknytning - i modsætning til et forsøg på at skjule egne følelser. Men det tilføjes lettere patetisk "hos en 'instrumentelt' orienteret person". Vi vidste det jo godt: mænd er nørder og nørder kan bedst relatere sig kommunikativt via højteknologisk apparatur - lad os dog bære over med dem. Netop den slags apparater kan betragtes som den udenfor ståendes adgang til informationer om, hvad der foregår på et tidspunkt, hvor kommunikati- 
onen fra den ellers primære kilde, moderen selv, ofte fremstår udifferentieret. Apparaturet er i stand til at levere en mere differentieret representation af aspekter af fødselsprocessen det er jo derfor det står der, sundhedspersonalet anvender det i selvsamme øjemed. Her ville en mere etnografisk tilgang kunne gøre nytte som baggrund for analysen af, hvad der egentlig foregår på fødestuen.

Interviewene med jordemødrene giver faktisk en god belysning. Det var i dette kapitel, at fædrenes situation for alvor blev tydelig for nærværende læser. Her leveres en levende beskrivelse og informationer, der bevæger sig ud over niveauet for tilfredshedsundersøgelser. Som nævnt peger nogle jordemødre på, at fædrene kan have en funktion i kommunikationen med moderen, nemlig som den der kan nå ind til hende i kraft relationen. Set fra jordemødrenes synspunkt kan hans tilstedeværelse være en lettelse i deres arbejde.

Til sidst bliver bogen et rent politisk indlæg i den sundhedspolitiske debat, hvor der agiteres for ændringer i praksis på fødeafdelingerne og i fødselsforberedelsen. Argumenterne hentes først og fremmest fra undersøgelsen af fædrene og dernæst fra den mere generelle udviklingspsykologiske tilknytningsforskning.

Denne del virker svagt funderet og er til tider i fare for at fremstå skinger i tonefaldet. Hvis man virkelig ønsker at beskæftige sig med fædre og fødsler nytter det ikke noget at begrænse sig til at se på sundhedspolitikken og sundhedsvæsenets praksis. Socialpolitikken er mindst lige så vigtig og dertil en kritisk forholden til herskende dogmer om de rette holdninger. Selvfølgelig er det et indlysende væsentligt forslag, at fædre skal have mulighed for at overnatte sammen med mor og barn efter fødslen, men er det ikke også væsentligt at forbedre mænds barselsorlov? Bogens fundament for at anbefale generelle xndringer i den institutionelle praksis er for snævert, og det ville have klædt den at afstå fra så bastante afsluttende konklusioner. Især når den gennemgående kritik rettes mod "systemets" logik og forbedringsforslagene alle peger i retning af en $u d v i d e l s e$ af systemets praksisfelt.

Hvem henvender denne bog sig til? Efter flere gennemlæsninger er jeg stadig i tvivl, og hverken forfattere eller forlag kommer med noget forslag. Læs den for den historiske gennemgang af praksis omkring fødsler i Danmark eller for den empiriske del, hvoraf kapitlet om jordemødre er det bedste.

David T. Metz, Cand. Psych.
EN MOR BLIVER TIL
Daniel N. Stern, Nadia
Bruschweiler-Stern og Alison
Freeland: En mor bliver til -
hvordan oplevelsen af moder- skab forandrer dig for bestan- dig. Hans Reitzels Forlag, København, 1999. 211 sider, $225 \mathrm{kr}$.

Artællingen om Kvindens derskabsinstinkter - krydret med lidt diffus samfundsanalyse - kunne man med lidt frækhed benævne hovedingredienserne i den seneste bog af professor i psykologi og børnepsykiatri Daniel Stern. I samarbejde med børnepsykiateren (og ægtefællen) Nadia Bruschweiler-Stern og freelancejournalisten Alison Freeland har Stern udgivet et af de seneste skud på stammen af populærvidenskabelige bøger om forældreskab med overvejende fokus på moderskabet. I modsætning til en del af Daniel Sterns tidligere arbejder er der således ikke her tale om et videnskabeligt fagskrift. Målgruppen er eksplicit vordende og nuværende mødre og andre interesserede.

Hovedforfatteren Daniel Stern er en af tidens meget indflydelsesrige forskere og terapeuter indenfor det udviklingspsykologiske og børnekliniske felt. Tidligere er der på dansk udkommet en række bøger, hvoraf Barnets interpersonelle univers (1985) samt Et spedbarns dagbog (1990) nok er de mest kendte og citerede. Kendetegnende for Daniel Sterns arbejder er forsøget på at udvikle den psykoanalytiske forståelses- 
ramme ved hjælp af nyere udviklingspsykologisk forskning. At forene den eksperimentelle og kognitionsbaserede forskning med psykoanalysens subjektive perspektiv. Trods de for mig at se til tider ganske spekulative forsøg på at forstå det helt spæde barns oplevelsesverden er Sterns forskning et væsentligt bidrag til en dybere forståelse af den gensidighed og samregulering der finder sted hos det spæde barns interpersonelle relationer.

\section{En udviklingsrejse}

En mor bliver til er skrevet på baggrund af samtaler med en lang række kvinder forfatterne har haft kontakt til igennem deres arbejde. I bogen følger vi via tre kvinders fortællinger rejsen gennem den oplevelsesverden positionerne som ventende og ny mor tænkes at implicere. Det er en rejse der leder frem til det forfatterne betragter som det endelige mål; moderskabsindstillingen. En rejse der for den enkelte kvinde bevæger sig gennem såvel helt unikke, personlige konturer som mere fælles genkendelige.

Bogens struktur afspejler kronologien i denne udviklingsproces, der starter med en forberedelsesfase efterfulgt af tilblivelsesfasen frem til den endelige tilpasningsfase. "Forberedelsesfasen" udgør således bogens første del, og her er fokus rettet mod den gravide kvindes produktion af et imaginært barn, hvor drømme, fantasier, håb og frygt antages at dominere. Vi præsenteres herefter for tanker der er knyttet til selve den fysiske fødsel af barnet efterfulgt af de tidlige forestillinger om det nye konkrete barn. "Tilblivelsesfasen", hvor følelser af utilstrækkelighed, forvirring, glæde, udmattelse hævdes at opfylde kvinden udgør bogens midterste del. Der udpeges her to basale (og universelle?) moderskabsopgaver, nemlig at sikre barnets fysiske overlevelse samt etablering af en intim følelsesmæssig og kærlig relation til barnet. Udover disse to grundopgaver udpeges det at etablere et socialt støttende netværk som særlig afgørende i denne fase. Den særlige orientering mod andre kvinder i deres funktion som rollemodeller for moderskabet hævdes her at være dominerende. Endelige omhandler tredje og sidste del af bogen tilpasningsfasen, og der inddrages her temaet om kvindens nye opgave med at integrere den nye mentale indstilling i sin identitet. En af de vanskelige punkter her hævder forfatterne er spørgsmålet om at kunne forene arbejdsliv og familieliv.

Det er således transformationen fra kvinde til moder, som den tænkes at finde sted gennem disse forskellige faser i livet omkring barnets fødsel, der optager forfatterne i denne bog. Faser der sammen udgør den proces der i sidste ende muliggør "fødslen" af "moderskabsindstillingen" der tænkes at stå i forgrunden for alt hos den nye moder. En proces, hvis omfang og implikationer ifølge forfatterne er et hidtil overset fænomen. Som gennemgående figurer møder vi som sagt tre kvinder, der hver især fortæller deres på én gang unikke og fælles historie om at blive mødre.

\section{Den nye triade}

Diskussionen med den traditionelle psykoanalyse, der er et gennemgående tema i Sterns produktion er også at finde i denne seneste bog, dog er det denne gang ikke barnets men derimod alene moderens psykiske organisering og udvikling, der er i fokus. Det nye i bogen, der i øvrigt er en populær bearbejdning af dele af den mere teoretiske og terapeutisk orienterede bog "Moderskabskonstellationen" (Daniel Stern: The Motherhood Constellation. Basic Books, 1995), er opgøret med den traditionelle psykoanalytiske forestilling om den ødipale triade som den organiserende konstellation i den menneskelige psyke. En grundlæggende psykisk organisering, der tænkes at vedvare livet igennem. Stern hævder at der i løbet af kvindens graviditet og i månederne efter fødslen er tale om udviklingen af en anden konstellation, nemlig moderskabskonstellationen, der for en tid virker som det dominerende i det psykiskes organisering hos kvinder. Der er ikke tale om en derivat af den ødipale konflikt, i stedet tænkes den ødipale triade bestående af mor - mors far mors mor at blive afløst af en ny triade, nemlig mor - mors mor - baby. Selvom konstellationen kun i en afgrænset periode er dominerende i kvindens psykiske liv er der, som undertitlen på bogen indikerer, tale om en bestandig forandring af kvindens indre psykiske landskab. Denne nye mentale ind- 
stilling, er måske nok mest fremtrædende i begyndelsen af moderskabet, men kan under de rette omstændigheder aktiveres og atter blive dominerende for en tid. Engang mor, altid mor er budskabet fra forfatterne.

\section{Et snævert perspektiv}

Med denne tænkning brydes der muligvis radikalt med en traditionel psykoanalytisk diskurs omkring den ødipale triades primat i det psykiskes organisering, men selve triade-forestillingen om det psykiskes organisering bevares i denne fremstilling. Det er ærgerligt da forfatterne hermed udelukker muligheden for et bredere og mere konkret historisk og sociologisk perspektiv. Eksempelvis ekskluderer denne teoretiske konstruktion kvinders positioneringer i forhold til ægtefæller/fædre i forbindelse med det identitetsarbejde moderskabet tænkes at implicere. De sparsomme 15 sider sidst i bogen der er reserveret det mandlige køn vidner om dette. Den dyadiske og triadiske forbliver således den snævre optik der benyttes, og efterlader spørgsmål om det situerede moderskab. For eksempel understreger forfatterne flere steder at moderskabet udvikles i en bestemt historisk, kulturel kontekst, men gør ikke disse forhold til egentlige analysekategorier i bogen. Eksempelvis skrives et sted: "som nybagt mor skal du ikke alene forholde dig til forandringer i dit indre landskab, men også til særegenhederne ved vores samfund og vores tid i historien, hvilket yderligere påvirker din udvikling som mor" (s. 19). Problemet i fremstillingen bliver for mig at se en manglende kobling mellem det indre landskab og det ydre - samfundet. Det der præsenteres bliver en fortælling om kulturens påvirkning af det naturlige, dvs. en udvendig relation, hvor overvejelser omkring konstruktionen af hvad der er natur/kultur slet ikke indgår. Et andet sted skriver forfatterne: "Mens din overtagelse af ansvaret for dit barns fysiske overlevelse er en test af din tilstrækkelighed som naturligt dyr, er dette intime ansvar for at danne et kærligt bånd til dit barn en test af din tilstrækkelighed som naturligt menneske" (s. 102). Kultur og samfundsmæssighed fremstilles her ikke som sådan konstituerende for mennesket, men som noget der virker ind på noget allerede eksisterende, nemlig det naturlige menneske. Og selvom forfatterne bogen igennem forsøger at være ikke dømmende i forhold til forskellige kvinders forskellige måder at udvikle deres moderskabsindstilling på, ligger der i bogen alligevel en forestilling om, at noget er mere naturligt (og dermed mere rigtigt!) end andet. Eksempelvis er der ikke stor forståelse for hvorfor mødre uden nogen økonomisk nødvendighed vælger at genoptage deres arbejdsliv udenfor hjemmet i det spæde barns liv. Der udpeges i stedet et naturligt tidspunkt for genoptagelse af arbejdet udenfor hjemmet ved barnets andet leveår - udfra en argumentation om, at barnet først her har en mere stabil tilknytning til moderen, og derfor er i stand til at op- retholde denne trods moderens fravær. Nogen egentlig videnskabelig dokumentation for dette leveres ikke, ej heller en overvejelse om hvorvidt størstedelen af børn i dele af verden i dag, hvor kvinder er udearbejdende i barnets spæde liv får problemer i deres tilknytningsrelationer?

Trods det snævre teoretiske perspektiv indeholder bogen alligevel flere interessante afsnit. Navnlig kapitel tre, hvor forekomsten af selvopfyldende profetier og nye roller tematiseres, introducerer et spændende felt, der drejer sig om forholdet mellem forestillinger og handlinger. Her tages fat på de forskellige ofte uudtalte funktioner det ufødte og nyfødte barn tildeles af forældrene. Nogle af disse er eksempelvis karakteriseret ved at barnet skal udfylde et særligt formål blandt andet at udbedre forskellige konfliktuelle problemstillinger i dets nærmeste relationer. Barnet bliver derved et redskab andre kan bruge til noget i højere grad end en aktør der handler i forhold til at realisere egne mål. Ikke at realiseringen af egne mål nødvendigvis udelukker realisering af fælles mål, men det er væsentligt, fastslår forfatterne, at disse uudtalte forventninger og forestillinger bliver reflekteret bevidst for at undgå en problematisk udvikling i relationen mellem barnet og dets omsorgspersoner. Endvidere gøres det klart, at der ikke nødvendigvis er tale om noget patologisk, idet disse forestillinger samtidig er nødvendige for den proces der leder frem mod 
moderskabsindstillingen.

De tre kvindeportrætter er også interessante og formentlig vil aspekter af deres historier vække genkendelse hos mange kvinder.

Bogen er som sagt ikke en videnskabelig fremstilling og målgruppen er primært kvinder der venter sig eller er blevet mødre - en bog af typen "What to Expect When You're Expecting". Set i dette lys er det bestemt et af de bedre bidrag, blandt andet i kraft af forsøget på at legitimere et meget blandet følelsesregister i forbindelse med moderskabet og budskabet om at moderskabsfølelser ikke er noget der udvikles på en gang, men netop er en længere proces, der kan have forskellige fremtrædelsesformer. Også pointen omkring at moderskabet ikke blot er et individuelt projekt, men netop noget der udvikles i relation til andre og i en given kulturel, historisk kontekst. Men om denne type af bøger nødvendigvis behøver at implicere et absolut fravær af litteraturhenvisninger eller dokumentation for de påstande der fremsættes udover en diffus henvisning til forfatternes og her i særdeleshed hovedforfatteren Daniel Sterns 40-årige virke som psykiater/psykolog er et spørgsmål.

Maja Helweg-Jorgensen, ekstern lektor i udviklingspsykologi, Institut for Psykologi, Københavns Universitet.

\section{KØN, VIRKSOMHED \& KOMPETENCE}

Eva Bendix Petersen: Køn, virksombed \& kompetence. Arbejdspapir nr. 6, Kon i den akademiske organisation. København 1999. 95 sider. Gratis

$\mathrm{R}$ apporten er en revideret udgave af forfatterens kandidatafhandling i psykologi fra Roskilde Universitetscenter, og emnet er kønsbarrierer i den danske forsknings- og uddannelsesverden. Arbejdet er delvis foregået under forfatterens ansættelse som studentermedarbejder for projektet $K ø n i$ den akademiske organisation.

I indledningen gennemgår Eva Bendix forskellige forklaringer på mands-dominansen $\mathrm{i}$ forskerstillinger, der har været fremført, overvejende hentet fra den hjemlige debat: efterslæb, kvinders større familieforpligtelser, manglende kvindelige rollemodeller og diskrimination, og det begrundes, hvorfor der er valgt at sætte fokus på selve ansættelsesprocessen og specifikt bedømmelsesarbejdet, og for valget af metoden, kvalitative interviews med forskere med erfaringer fra deltagelse i bedømmelsesudvalg. I kapitel 1 redegøres for de teoretiske og metodologiske begreber og overvejelser, der har styret undersøgelsen, socialkonstruktivisme og dekonstruktion, og dernæst følger en presentation af den praktiske fremgangsmåde, som har bestået $\mathrm{i}$ interviews med fem forskere fra forskellige fagområder og institutioner, tre mænd og to kvinder. Kapitel 3 præsenterer analysen af de fem interviews med henblik på at afdæk- ke svarpersonernes opfattelser af faglige bedømmelser og betydningen af køn i denne sammenhæng. Endelig indeholder kapitel 4 en opsamlende og perspektiverende analyse af hovedresultaterne og en diskussion af mulige kønspolitiske implikationer.

Ser vi på selve interviewresultaterne, er det umiddelbart fremtrædende, at alle fem svarpersoner siger, de/man forsøger at foretage bedømmelser alene på basis af ansøgernes faglige meritter uden hensyn til irrelevante personlige kendetegn, at de godt ved, at den ideelle, strengt objektive faglige vurdering er en vanskelig sag, og at køn er irrelevant i den faglige bedømmelse. Det gxlder både med hensyn til ansøgernes køn og med hensyn til bedømmernes. Hermed udtrykker de tilslutning til centrale værdier i moderne videnskab om universalisme og neutralitet, kendt bla. fra sociologen Robert K. Mertons CUDOS-normsæt, ifølge hvilken en af grundnormerne i moderne videnskabs "etos" er, at videnskabelige resultater "skal vurderes efter upersonlige, forud fastsatte kriterier" og ikke efter "personlige eller sociale egenskaber ved deres fortalere, såsom race, nationalitet, religion, klasse . ..”. Det er også, hvad der forudsættes i de formelle ansættelsesregler.

Det er indtrykket på facaden, hvad ikke kan undre. Dommere vil sikkert også sige, de prøver at dømme efter loven, læger at de forsøger at overholde lægeløftet osv., og det viser en begrænsning $i$ interviewmetodik i forhold til et 
sådant emne. Bendix forsøger på forskellige måder at "dekonstruere" sig om bag facaden. Udformning og tolkning af stillingsopslag og sam-

mensætning af bedømmelsesudvalg spiller en vigtig rolle. Der udtrykkes også det synspunkt, at ledelsen ved rekruttering bør have et vist personalepolitisk spillerum, herunder mulighed for at inddrage overordnede hensyn til fagmiljø mv. Bendix hæfter sig desuden ved rapportering om, at andre forhold end (skriftlig) faglig produktion, såsom udlandsophold og samarbejdsevne, kan inddrages, men at de i så fald skal "fagliggøres", dvs. det skal forklares, hvordan de manifesterer sig i faglige kompetencer eller resultater.

Angående køn er en iagttagelse, at emnet for svarpersonerne var et "urovækkende tema", når det blev bragt frem, og fremkaldte ubehagelige og ligefrem pinagtige situationer. Her skal det siges, at svarpersonerne ikke på forhånd var orienteret om, at dette var centralt i undersøgelsen. De kvindelige svarpersoner siges at reagere ved at "lægge afstand mellem dem selv som akademiske aktører og deres køn". Her må jeg sige, at jeg strengt taget ikke helt kan få øje på dokumentationen for, at det er deres køn som sådan, de lægger afstand til. De mandlige er tilbøjelige til blot at omtale køn som irrelevant på linie med andre sociale kendetegn (s. 66).

I det afsluttende, opsamlende og perspektiverende kapitel er det mest interessante efter min mening diskussionen af de mulige kønspolitiske aspekter.
Der er ikke tale om helt håndfaste og konkrete forslag, men et hovedpunkt er, at man i stedet for at søge efter mere objektive kriterier "bør opgive muligheden for absolut vurdering" og som konsekvens beslutte, at "ansøgernes køn er et af de systemkrav der skal opfyldes - udfra demokratiske retfærdighedshensyn". Bendix siger videre, at "Den eneste bevæggrund man kan have for $i k$ $k e$ at bakke op om de konkrete handlingsinitiativer er manglende demokratisk indstilling" (s. 91). Det præciseres ikke, hvilke handlingsinitiativer, der tænkes på, og jeg mener nok, at det er en meget håndfast $\mathrm{og}$ generaliserende konklusion, som ikke er underbygget. Svarpersonerne refereres for eksempel for enighed om, at reglen om kvindelige medlemmer af bedømmelsesudvalg "var fjollet og ligegyldig” (s. 62). Er der belæg for at affeje det som udtryk for manglende demokratisk indstilling? Eksemplet peger på en af de svagheder, jeg som (vil jeg mene) nogenlunde oplyst iagttager, men ikke særligt aktiv deltager, ser i debatten om ligestilling $\mathrm{i}$ forskningen, at vi har forsømt at gå i dybden med eksplicitering og analyse af de principper, der er i spil. Det må være en af de ting, vi som forskere især kan bidrage med. Her drejer det sig om forholdet mellem et videnskabssyn, der indebærer eliteorienterede, universalistiske meriteringsnormer på basis af faglige præstationer og demokratiske retfærdighedshensyn. Det er en fortjeneste, at rapporten fremdrager dette spørgsmål, men så lidt som faglige kvalifikationer kan bestemmes absolut, lader det sig gøre med demokratiske retfærdighedshensyn. Der er behov for en udredning af, hvad demokratiske retfærdighedshensyn betyder på dette område foreksempel i lyset af den klassiske sondring mellem lighed $i$ formelle rettigheder, i reelle muligheder og i resultat med hensyn til fordeling. Den foregik i 1960'erne og 1970'erne med hensyn til ulighed mellem sociale lag, men døde, og i hvert fald kan man se, at resultatligheden er taget af den politiske dagsorden efter at velfærdsstaten kom under kritik og individualisme og neoliberalisme vandt frem fra slutningen af 1970'erne. Denne principelle diskussion fortjener at blive genoplivet. Der er også behov for mere dybtgående diskussion af, om der er modsætning mellem disse principper - Merton og mange andre har jo hævdet, at det er der ikke, tværtimod er de indbygget i hinanden - og en diskussion af, hvordan man skal afveje, hvis der er modsætning. Diskussionerne har sikkert foregået, men jeg synes ikke de har været ret synlige i den hjemlige debat, og omtales i hvert fald ikke i rapporten.

Samlet synes jeg imidlertid, der er tale om en interessant og læseværdig rapport. Træder man lidt på afstand, tyder den på, at selve bedømmelsesprocessen nok ikke er en central kilde til kønsuligheden i forskningen. En stærkere inddragelse af de mange videnskabssociologiske studier, der findes i forvejen af stratifikation, peer review mv., såvel som specielt 
af kønsuligheder i forskningen (de anvendes næsten ikke), kunne have hjulpet til at lede undersøgelsen på sporet af mere centrale mekanismer.

Heine Andersen

Sociologisk Institut,

Københavns Universitet

\section{FEMINISME OG LITTERATUR- VIDENSKAB}

Feminisme og litteraturvidenskab, Kơ 88 , 27. årg. nr. 2/1999. Medusa, Holte. 208 sider, $160 \mathrm{kr}$.

\section{Teminisme og litteraturvi- \\ $\mathcal{C}$ denskab er titlen på det se-} neste nummer af $K$ \& $K$. Ambitionen er at fremme refleksionen over nøglebegreber i den feministiske litteraturvidenskab. Det konkrete udgangspunkt er to seminarer afholdt på Institut for Litteraturvidenskab i 1996 og 1997 med temaerne "Gender, Writing, and Women as Authors" og "Gender and Genre". Initiativet er prisværdigt på enhver måde.

Det er længe siden, der sidst er blevet taget initiativ til at sætte liv i den litteraturvidenskabelige dimension af kønsforskningen, og det er pragtfuldt, at vi, der ikke deltog i seminarerne, får adgang til flere af de centrale bidrag.

$K \ll K n r .88$ indeholder ti artikler og tre anmeldelser. Artiklerne falder indholdsmæssigt i to grupper. En første, der har feminismen dvs. det vi almindeligvis i Danmark kalder kvinde- og kønsforskningen, og dens teoretiske diskussion om kønsbegreber som omdrejningspunkt. Og en anden del der sætter fokus på køn og litteratur.

Lise Busk-Jensen indleder med "Veje og vildveje i feministisk litteraturvidenskab". Artiklens erklærede mål er "at forfølge nogle af de generelle diskussioner inden for feminismen ... for at overveje, hvilken betydning de har eller kan få for den feministiske litteraturforskning ...” (s. 18). Artiklen gennemgår grunddigt og systematisk den teoretiske udvikling og diskussion af kønsbegreberne inden for den amerikanske feministiske forskning og den rolle, den spiller for litteraturforskningen, og omvendt den rolle litteraturforskningen spiller i den feministiske forskning. Desværre indtager den danske kønsdiskussion en perifer rolle, om end der refereres til den. Statusopgørelsen peger på, at den feministiske forskning befinder sig i en art dødvande indespærret i sine egne teoretiske labyrint. Margaret Homans fremstiller i sit bidrag "Race, køn og kvindelige forfattere i USA" diskussionen om køn og race klart og informationsrigt. Men artiklens force ligger et andet sted i dens tanke om, at kønnet må opfattes som en af flere konkurrerende bestanddele i en forfatteridentitet.

Selv om de to første artikler på enhver måde både er oplysende og anbefalelsesværdige for dem, der interesserer sig for feminismens status og dens interne diskussioner i Amerika, så forekommer artiklernes problemstillinger perifere set $\mathrm{i}$ dansk sammenhæng. For det første hersker der i dansk kønsforskning langt større konsensus om, hvordan forskningen kan omgås køn som analytisk kategori uden at ende i en teoretisk labyrint end der tilsyneladende er i amerikansk. For det andet er diskussionen om forholdet mellem race og køn, der fylder meget i de første artikler, stort set fraværende i dansk feministisk litteraturforskning, og det med rette. Racespørgsmål har først for nylig fået relevans i dansk sammenhæng.

De specifikke litteraturvidenskabelige artikler er stærkt værk- og tekstorienterede. Materialet er dominant engelskamerikansk: Walt Whitman, Emily Dickinson, Virginia Woolf, om end der er afstikkere til det tyske: Rilke og det norske: Camilla Collett. Projekterne i artiklerne holder sig i store træk inden for feltet af kanoniserede, feministiske teser. I bidraget "I min slutning er min begyndelse'. Skabelsen af oprindelse og elegi hos Whitman og Dickinson" fremlægger notabiliteten Sandra M. Gilbert den tese, at kønsforskellen fortrinsvis kan lokaliseres på den poetiske genres niveau. Forskellen mellem den mandlige og kvindelige forfatters værker fremstår i høj grad i deres forskellige forpligtelse på traditionen. Hvor den mandlige forfatter synes bundet af traditionen, står den kvindelige forfatter friere og er som følge heraf mere original i sit udtryk. Dette medfører dog ikke, at mandlige forfatteres værker er dårligere end de kvindeliges. Ide Hejlskov Larsen tager i "Mytisk struktur og poetisk 
form i Walt Whitmans og Emily Dickinsons lyrik" fat på de to forfatteres positioner i forhold til den amerikanske adammyte. Hun viser med grundighed og stor indsigt, men ikke synderligt overraskende, at Walt Whitman igennem hierarkier søger enhed i splittelsen, mens Dickinson snarere lader sin $x$ stetik videregive et eksplosivt og fragmenteret verdensbillede. Lilian Munk Rösing fremlægger i "Eurydikes blik" tesen om, at "der i den poetik de tre herrer [Rilke, Blanchot og de Man] lader figuren [Eurydike] være billede på, ligger en implicit kønsfilosofi, og at det er denne kønsfilosofi, der skal ændres, hvis der skal rykkes ved poetikken eller sprogfilosofien" (s.113). Både Tania Ørum og Ida Klitgård har Virgina Woolfs The Waves som genstand for deres bidrag. Tania Ørum skriver om "Romanen som skuespil og digt" og påviser overbevisende, hvordan Woolf ved at overskride genregrænserne og sammenføje romanen med poetiske og dramatiske elementer placerer sig centralt i en modernistisk strømning. Ida Klitgård er en anelse mere radikal i sin synsvinkel på Woolfs roman. Hun anskuer det sublime i det små og det store med afsæt i den romantiske $x$ stetik-filosofiske diskussion: Burke og Kant. Begge analyser fremstår som led i en kanonisering af Woolfs roman baseret på det argument, at den rummer en kompleksitet helt på højde med den, der findes hos de samtidige mandlige modernister.

Især to bidrag bør frem- hæves. Det ene primært for sin litteraturvidenskabelige indsats og den andet for sit bidrag til kvindelitteraturforskningen. Den første er Karin Sanders artikel "Fanget mellem ord og billede. Betragtninger over ekfraseteorier og køn", som nok er temanummerets bedste og mest fokuserede. Den rummer en kortfattet introduktion til begrebet ekfrase og de forskellige teoretiske positioner. Som den eneste henter hun sit analysemateriale fra dansk litteratur - nemlig Chr. Winters novelle "Skriftestolen" fra Fire Noveller (1843). Selv om novelleanalysen er kort, er den fintmærkende, og selv om Karin Sanders fokuserer skarpt på sin problematik, får hun den elegant placeret i novellens totalitet. Fra en umiddelbar betragtning har ekfraseteorierne intet med køn at gøre, men det får de. Med skarpt formulerede gengivelser af hovedpunkterne i Mitchells teorier om ekfrasen viser Karin Sanders, hvordan ekfrasen kønskodes både teoretisk og i litteraturen. Den anden artikel er Jorunn Hareides. I sin artikel "En kvinnelig forfatters skall. Camilla Colletts synspunkter på kvinners forfatterrolle" afsøger hun den nævnte forfatterindes poetik igennem en indsigtsfuld læsning af hendes breve og essays. Afslutningsvis kan Jorunn Hareide overbevisende konstatere, at halvfjerdserfeminismens afvisning af forfatterskabet som reaktionært var en gedigen fejltagelse.

Johan Fjord Jensens bidrag "Erindringer i utide. En art anmeldelse af Nordisk kvindelitteraturbistorie" danner en overgang mellem artiklerne og anmeldelserne. En af de gode pointer hos Fjord Jensen er i overskriftsform, at den grundlæggende konflikt for "Nordisk kvindelitteraturhistorie er, at den er blevet til i en periode, der troede på betydningen af de store fortxllinger, men at den er blevet skrevet og nu udgives i en periode, hvor man har mistet tilliden til sådanne fortællinger" (s. 186). Kن́K $n r .88$ afsluttes med tre anmeldelser. Elisabeth Møller Jensen tager sig af Toril Mois Simone de Beauvoir. Hur man skaper en kvinnlig intellektuell. Lilian Munk Rösing skriver om Lotte Tranes Langselsbilleder. En beretning om forforelse, skrift og passion, mens Inge Lise

Rasmussen går Anne Scott

Sørensensens antologi Nordisk Salonkultur. Et studie i nordiske skønånder og salonmiljøer efter i sømmene.

I det omfang Feminisme og litteraturvidenskab repræsenterer dansk feministisk litteraturforskning i dag kan det konstateres, at tidligere tiders beklagelser over den feministiske litteraturvidenskabs faglige niveau ikke kan gentages. Artiklerne oser af belæsthed, teoretisk indsigt og analytisk kreativitet. Knebent ser det derimod ud mht. fantasien og nytænkningen inden for det kønsanalytiske felt. Vel er der fornyelser og interesse for sammenstillinger af mandlige og kvindelige forfattere. Og forskellige filosofiske indfaldsvinkler skaber også nye indsigter i kønnet. Men i sidste ende hænger artiklerne med enkelte undtagelser fast i en moderni- 
stisk tænkning i dikotomier og deres overskridelse.

Samlet tegner Feminisme og litteraturvidenskab et billede af en dansk forskningsgren, der henter sin inspiration fra USA og som sjældent selv producerer noget teoretisk værdifuldt og hvis præstationer ligger på det værkanalytiske og litteraturhistoriske felt. Ved at fokusere så ensidigt på amerikansk feministisk forskning og næsten overse den danske marginaliserer $K \mho \leftarrow K$ dansk kønsforskning. At dansk kønsforskning er marginal i forhold til amerikansk forskning, skal jeg ikke bestride, men det behøver jo ikke nødvendigvis at føre til at den også skal være det for os, der lever og læser her i Danmark.

Endnu mere bizart forekommer det mig, at dansk og nordisk litteratur er blevet en parentes i dansk litteraturforskning. Hvordan kan det være, at kun et nordisk forfatterskab og en enkel dansk novelle har fundet sin plads? Lige så undrende stiller jeg mig overfor det faktum, at ingen af artiklerne går i klinch med litteratur affattet efter anden verdenskrig. Det ville have været interessant at se de litteraturvidenskabelige teser afprøvet på såvel nutidig litteratur som en mindre kanoniseret litteratur. Heller ikke dansk litteraturvidenskab synes forfatterne at have særlig høje tanker om. Referencerne til danske litteraturforskere og deres præstationer skal man lede godt efter.

Min konklusionen er kort og godt, at Feminisme og litteraturvidenskab som projekt er et godt og modigt initiativ, men også at horisonten på en gang er for snæver og alt for fjern.

Annemette Hejlsted, ph.d., Center for kvinde- og kønsstudier, Københavns Universitet

\section{DE BLØDE PUNKTER}

Jette Hansen: Det blode punkt. Kvindeidentitet $i$ '90'erne. Tiderne Skifter, 1999, København. 270 sider, 268 kroner.

\section{Hanne-Vibeke Holst: Min} mosters migrone eller hvordan jeg blev kvinde. Gyldendal, 1999, København. 329 sider, 250 kroner.

I efteråret kom feminisme, ligestilling, og køn endnu engang på mediernes dagsorden. Det nye startskud kom med den svenske bog Fittstim, på dansk Fisseflokken, der igen bragte feminisme i mediernes søgelys, med en række unge kvinders vidnesbyrd om at vokse op i et samfund, hvor kønnet stadig strukturerer muligheder og relationer. Foruden Fisseflokken har debatb øgerne Det blode punkt. Kvindeidentitet $i$ '90'erne af Jette Hansen og Min mosters migrene eller hvordan jeg blev kvinde af Hanne-Vibeke Holst præget efterårets diskussioner. Med stor energi tager disse to forfattere afsæt i såvel egne som andres erfaringer og diskuterer kønsidentitet og kvindeliv med familie- og kærlighedsrelationer som omdrejningspunkter.

I Det bløde punkt... analyserer Jette Hansen en række popu- lære værker skrevet af kvindelige forfattere: Susanne Giezes

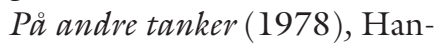
ne-Vibeke Holsts trilogi om Therese Skårup: Thereses tilstand (1992), Det virkelige liv (1994) og En lykkelig kvinde (1998), Isabella Smiths En flirt mellem venner (1997) og antologien Adskillelse, redigeret af May Schack (1993). Hansen læser disse værker som udtryk for forfatternes opfattelser af kvinde- og kønsidentiteter og inddrager desuden sin egen historie om og forståelse af at blive (kvinde)kønnet. $\mathrm{Og}$ sin indignation. For som hun konstaterer på bogens første linjer, er det et helvedes problem at være kvinde! Løsningen må da være at få sig en kone ... En kone til at overtage ansvaret, overblikket og den følelsesmæssige og praktiske kontinuitet i børnefamilierne, så man i ro og fred kan koncentrere sig om realiseringen af et succesfuldt arbejdsliv. Men kvinder har som bekendt ikke koner (i den heteroseksuelle og far-mor-og-børn-optik som bogen bevæger sig indenfor), og problemet med at få familie- og arbejdsliv til at hænge sammen er således i Hansens bog et kvindeproblem. Det er kvinder, der sidder i saksen "mellem empati og selvafgrænsning, symbiose og individualitet" (s. 20). Det er kvinder, der enten må "amputere [deres] væsen og føleevne og deltage i rotteræset" eller "hutle sig igennem mere eller mindre som en randeksistens på kanten af samfundet med bevidstheden om at være en paria, mens menneskehedens anden halvdel, mændene, står 
ovre på den anden side, velbjærgede, gabende som en flok tåber: de kan ikke se der er noget problem" (s. 22).

I de nævnte værker udforsker Hansen så denne problematik. Og i hver læsning tegner sig det samme mønster: når de kvindelige hovedpersoner får børn, ændrer det fundamentalt deres liv, men stort set ikke deres mænds. Kvinderne tager ansvar for familierne, mændene gør ikke. Kvinderne udfører det reproduktive arbejde uden at stille større krav til mændene (Hanne-Vibeke Holsts Therese skifter dog sin ud til sidst) og samfundet. På trods af kvindefrigørelse og tilsyneladende ligestilling. For kvinderne har et blødt punkt - nogle stærke følelser omkring seksualitet og moderskab, som opleves som overvældende og lidt utilregnelige. Følelser som ikke tematiseres politisk. Dette er derimod Jette Hansens ærinde; at rejse en debat om kvindernes og familiernes vilkår i det moderne - i et ligestillings perspektiv.

Analysen er, at kvinder når de får børn, oplever en form for utilpassethed og ambivalens i forhold til det øvrige samfund. Der er dog ingen ambivalens i forfatterens udlægning af hvem, der har problemet, nemlig kvinderne. Denne skarpskårne entydighed går i gennem hele bogen, hvor Hansen uden at tøve skriver om kvinde $n$, manden, kønsrolle $n$ etc. Denne generalisering rejser et vigtigt spørgsmål: hvad er forholdet mellem den nødvendige politiske tematisering af kønsrelationerne og den lige så nødvendige dekon- struktion af 'kvinden' og 'manden'. Som Hansen skriver er italesættelsen af kønnet samtidig en fortolkning af kønnet taler man om kvinder og undertrykthed, bidrager man på paradoksal vis til forestillingen om kvinder som undertrykte. Men, som hun også skriver, nytter det ikke noget at lade være med at tematisere kvinders problemer, "fordi man ikke vil have at kvindeligheden skal være problematisk" (s. 266). Jette Hansen tier da heller ikke, men har derimod det ambitiøse ønske at ændre kulturens (læs mændenes) værdisystem, så det reproduktive arbejde anerkendes og værdsættes. Så løsningen er ikke at få sig en kone. For denne løsning er blot at skubbe arbejdet videre: det overtages af andre, oftest kvinder med lavere social status, færre valgmuligheder og, kunne man tilføje, ofte af anden etnicitet.

Jeg synes Det bløde punkt er vigtig og provokerende, som politisk/polemisk indlæg. Men nuancerne ryger i svinget. Ikke alle mænd er hårde, ikke alle kvinder bløde og ansvarlige. Alligevel er bogen et godt oplæg til at diskutere videre fra, hvis man vel at mærke husker nuancerne og flertydigheden.

\section{Min mosters migrane eller} bvordan jeg blev kvinde er det ikke så meget balancegangen mellem at have børn og karriere, men først og fremmest relationen mellem kønnene; i parforholdet, på arbejdet og i forhold til faderen, der er til diskussion. Hanne-Vibeke Holst fortæller sin egen, søstrenes og moderens og mormoderens hi- storie i hendes selvbiografiske odyssé om 'at blive kvinde' i en Simone de Beauvoir'sk forstand. Med udgangspunkt i denne kollektive historie påkalder hun sig genkendelsen hos sine læsere; at vore historier om at blive kønnede måske ikke er så forskellige endda. At 'køn og skæbne' hænger sammen, som hun skriver. Derfor kan Min mosters migrene ... både læses som et stykke bekendelseslitteratur og som Holsts personlige påvisning af, at køn er historisk og strukturelt betinget, og ikke bare er noget man skaber forfra hver dag, som en af hendes bekendte, skuespilleren, udtrykker det (s. 250).

Til at starte med ville forfatteren dog have skrevet en rigtig klogebog, der en gang for alle beviste uligestillingen, sådan så hun "ikke længere skulle diskutere, om der er kønsforskelle, men hvorfor de stadig er så markante" (s. 9). Hun forkaster imidlertid den akademiske form til fordel for den personlige historie. (Bente Rosenbecks Kvindekøn (1987) burde have vist, at de to projekter kan forenes, men det er en anden historie.) I Min mosters migrene ... fortæller Holst så de kvindelige familiemedlemmers historier - eller rettere om deres forhold til mænd. Søstrenes og mormoderens stemmer gengives i dokumentarstil, mens Holst egne historier finder flere krogede stier at gå ad. Underbevidstheden skriver med i form af nogle spektakulære drømme; erindringer og erkendelser dukker frem af influenzaens febertåger og til flamencotimer. Holst 
fortæller om barndommen som 'pigen med fletningerne' i Vestjylland, om ønsket om at være one of the boyz, om at være journalistsild og ' 80 'er chick, om tilværelsen som diplomatfrue og forfatter i Moskva. Med pumps og hushjælp.

Men altså ikke mindst om mændene, parforholdene. Ægteskabet er et afgørende punkt i dét at blive kvinde, skriver Holst, og hendes eget xgteskabelige opgør står derfor centralt i forståelsen af kvinders position. Det er først og fremmest i relationen til manden, at kvinder undertrykkes, og vejen til frigørelse er først bevidstgørelse og derefter oprør. Det drejer sig nemlig om at vælge. Holsts bud på kønsproblematikkernes løsning for den enkelte kvinde, er at vælge "Den Rigtige Mand" og der- med fravælge de patriarkalske xgtemænd og -skaber, der undertrykker kvinders selvrealisering. Hun konstaterer at hun "har været betydelig mere undertrykt" end hun egentlig troede (s. 326); at hun har været bevidstgjort, men ikke frigjort. Fri bliver hun, ikke ved at være alene, men ved at indgå i et ligestillet og -værdigt parforhold med en mand, der tager sin del af slæbet. Holst skynder sig dog at forsikre læserne, at manden er yderst maskulin, og at der hjemme hos dem er den fineste balance mellem det feminine og det maskuline. Så budskabet i Min mosters migrone .... er, at kønnet har en strukturerende betydning, og at det er i relationen til manden, at 'man bliver kvinde'. Men også, at man som kvinde kan frigøre sig fra undertrykkelsen uden at give køb på selve 'feminiteten', der ikke på afgørende vis problematiseres i bogen. Holst afslutter sin bog med at citere idolet Beauvoir: "Man fødes ikke som kvinde, man bliver det." Og forsætter: "Men hvilken kvinde. Det er valget" (s. 328). Man kan selvfølgelig kun give Holst ret $\mathrm{i}$, at de individuelle valg er vigtige, for kvinder som mænd. Det er bare ikke nok at slutte der.

Jeg synes ikke, at Min mosters migrane .... når så langt som den faktisk kunne. Men bogen er underholdende og kan måske give læserne inspiration til at tænke videre over egne kønnede familiehistorier.

Nauja Kleist

Stud. mag., RUC 